\title{
Sharing Design Rights: A Commons Approach for Developing Infrastructure
}

\section{Citation}

Gil, Nuno, and Carliss Y. Baldwin. "Sharing Design Rights: A Commons Approach for Developing Infrastructure." Harvard Business School Working Paper, No. 14-025, September 2013. (Revised January 2014.)

\section{Permanent link}

http://nrs.harvard.edu/urn-3:HUL.InstRepos:11508223

\section{Terms of Use}

This article was downloaded from Harvard University's DASH repository, and is made available under the terms and conditions applicable to Open Access Policy Articles, as set forth at http:// nrs.harvard.edu/urn-3:HUL.InstRepos:dash.current.terms-of-use\#OAP

\section{Share Your Story}

The Harvard community has made this article openly available.

Please share how this access benefits you. Submit a story.

Accessibility 
H A R VAR D

Sharing Design Rights: A
Commons Approach for
Developing Infrastructure

Nuno Gil

Carliss Y. Baldwin

\section{Working Paper}

14-025

January 21, 2014 


\title{
Sharing Design Rights: A Commons Approach for Developing Infrastructure
}

\author{
Nuno Gil* \\ Carliss Y. Baldwin ${ }^{\dagger}$
}

January 2014

*University of Manchester nuno.gil@mbs.ac.uk

${ }^{\dagger}$ Harvard Business School cbaldwin@hbs.edu 


\section{SHARING DESIGN RIGHTS: A COMMONS APPROACH FOR DEVELOPING INFRASTRUCTURE}

This study empirically investigates the relationship between design structure and organization structure in the context of new infrastructure development projects. Our research setting is a capital program to develop new school buildings in the city of Manchester, UK. Instead of creating a controlled, hierarchical organization, which would mirror the buildings' design structure, the Manchester City Council created a "commons organization," and chose to share decision-rights with local claimants. Each school's faculty was thus given rights equal to Council staff to participate in the design process and to approve the school's design. In the natural resources literature, commons theory predicts that, if a robust governance structure is created, this complex form of organizing gives claimants incentives to contribute to the enterprise whilst dampening collective action problems (Ostrom 1990). Here we extend this claim to the production of man-made artifacts. The design commons induced teachers to volunteer time and effort to communicate their practical knowledge, but created corresponding tensions over interdependent choices for the final design. Yet, none of the projects succumbed to collective action problems in the form of budget overruns, bogged-down processes, or users feeling disenfranchised. Applying Ostrom's (1990) principles of robust commons governance, we show that the Manchester design commons organization was robust by her criteria and propose that robustness contributed positively to the outcome. We also discuss design flexibility as an intervening variable that was critical in reconciling differences that governance alone could not resolve. We conclude with the rudiments of a theory describing when and why a commons organization can be advantageous for production of designs.

\section{INTRODUCTION}

Does the physical structure of a design constrain the structure of the organization that produces the design? Scholars commencing with Henderson and Clark (1990) have argued that design organizations will "come to mirror the internal structure of the product they are designing" (ibid. p. 27). This so-called "mirroring hypothesis" suggests that technology imposes a structure on organizations that produce designs. To avoid integration failure (Puranam and Goetting 2011), designs with high levels of designchoice interdependency (hence task interdependency in the design process) should be created by tight-knit teams with closely aligned incentives, generally lodged within a single firm (Thompson, 1967, Brooks 1973, Nickerson and Zenger 2004, Colfer and Baldwin 2010). Conversely, modular designs with low degrees of design-choice interdependency can be created by loosely coupled individuals with disparate knowledge and incentives, often lodged in different firms (Orton and Weick 1992, Langlois and Robertson 1992, Sanchez and Mahoney 1996, Fine 1998, Baldwin and Clark 2000, Colfer and Baldwin 2010, Puranam and Goetting 2011). Thus "the coordination tasks implicit in specific product designs 
largely determine the feasible organization designs for developing and producing those products" (Sanchez and Mahoney, 1996, p. 64).

However, simple versions of the mirroring hypothesis have been strongly challenged in theoretical work based on agent-based simulation models (Siggelkow and Levinthal 2003, Ethiraj and Levinthal 2004a,b), and by Puranam, Raveendran and Knudsen (2012), who argue that organization structure may be a response to ignorance, not underlying design structure: "designers shape organizational structures when they cannot shape task architectures: the latter requires ... a higher level of architectural knowledge." In empirical settings, simple mirroring is observed in many cases, but exceptions are not uncommon, and the reasons for their occurrence are not well understood (Colfer and Baldwin 2010, Dawson, Fixson and Whitney 2012, Lundrigan and Gil 2013). Hence there is need for further theoretical and empirical investigation of the relationship between design structures and organization structures, with special focus on cases that violate the prescription of simple mirroring.

This study addresses the need by investigating a class of problems underexplored in organization theory: the design of infrastructure projects. These capital assets, which include transport and telecommunication systems, utility networks, factories, hospitals, and schools, form the backbone of modern societies. ${ }^{1}$ Due to their long operating life and the scale and diversity of the resources required to build them, the development of new infrastructure directly affects many parties. Communities, operators, users, owners, funders, and regulators all have a stake in the outcome, thus may want to influence the design. Integrating their heterogeneous preferences and needs into a single design is hard, however, because many infrastructure assets have non-decomposable design structures in which no feature is independent of all others (Gil 2009, Gil and Tether 2011). Choices by one group will then (almost inevitably) conflict with choices by other groups. Previous empirical studies reveal that excluding parties from the design process attenuates conflict in the short run, but also often leads to costly late changes

1 The National Academy of Engineering 2008 report Grand Challenges for Engineering dubs infrastructure development one of the grand challenges for the new century. The McKinsey Global Institute (2013) estimates that the world needs to invest \$57 trillion on new infrastructure to keep up with projected economic growth through 2030, a 3.5\% of anticipated global GDP. 
and/or outright functional failure. As a result, infrastructure projects frequently run late, overrun budgets, and deliver outputs that leave many user groups and communities discontent (Morris 1994, Miller and Lessard 2001, Pitsis et al. 2003, Esty, 2004, Gil and Tether 2011).

While the design structure of an infrastructure asset is established by physics and technology and thus is hard to change, the structure of the corresponding design organization - the organization that produces the design - is usually a matter of choice to some degree. In general, some claimants will have design rights ex officio: they can retain those rights within a tightly focused, hierarchical organization or share rights with other groups, thus widening the scope and diversity of the design organization. This degree of discretion makes infrastructure projects a suitable setting in which to study the relationship between design structure and organization structure. As more parties share design rights, the potential misalignment between design structure and organization structure widens, and the parties must then reconcile their inconsistent beliefs and heterogeneous and conflicting needs to arrive at a functional whole. Thus the more parties with design rights, the greater the problems of collective action they will face (Libecap, 1989).

Given this dilemma, what logic should be used to determine who is included in the design organization of an infrastructure project? Furthermore, what challenges arise when the organization structure is misaligned with the underlying design structure in ways that give rise to collective action problems? Finally, when and how can the members of the design organization collectively resolve their differences to avoid delays, budget overruns and outright failure? These are the core questions that motivate this research.

Collective action problems have been extensively studied in the context of natural resources. According to Garrett Hardin (1968), who first identified the "tragedy of the commons," managing a collective asset requires either government regulation or private property rights. Mancur Olsen (1965) was similarly pessimistic about the ability of individuals to create and maintain collective goods. Without some form of compulsion, he argued, individuals will not voluntarily pay their proportional share of the 
cost of a collective good but will instead free ride.

Against the backdrop of these theories, Elinor Ostrom began to study how so-called "common pool" natural resources were actually managed (Ostrom 1990). Her research revealed that claimants to a common pool resource were frequently able to organize themselves to manage the resource collectively on a day-to-day basis and adapt to changing circumstances. The commons organizations in her field studies were characterized by multiple centers of power and nested levels of collective action and rule making, thus she called this form of organizing "polycentric governance."

According to Ostrom (2005), polycentric organizations can work in the presence of rules and forums where conflicts of interest and inconsistency of beliefs can be worked out, often through repeated face-toface interaction. Thus in a commons organization, polycentrism and hierarchical decision-making coexist. This form of organizing is complex, she admitted, but "complexity is not the same as chaos" (Ostrom 2010). She went on to elucidate a set of principles which can be used to assess the "robustness" of commons organizations, i.e., which ones are more likely to succeed and which are prone to failure.

Our focal setting in this research is a design organization created by the Manchester City Council (hereafter the Council) to design new school buildings. The national government gave the Council broad decision rights over school design, but rather than retaining those rights, the Council set up a complex "meta-organization" (Gulati et al. 2012) involving the schools' faculties, Council staff, and contractors. Significantly, the Council gave each school's faculty co-equal rights to approve the design so that no building project could go forward unless signed off by both the school and the Council staff. In this way, the Council chose to implement the schools' design process using a commons organization subject to collective decision-making instead of adopting a more centralized approach controlled by the Council staff.

We conducted qualitative, inductive research on six school design projects during the "first wave" of the Manchester school building program. Our initial purpose was to build grounded theory around the question: can an organization based on collective decision-making effectively carry out a highly 
interdependent, non-decomposable design process? As the data accumulated, three subsidiary questions arose: had a commons organization been created to design the Manchester schools? Was this organization robust according to Ostrom's principles of commons governance? And does robustness contribute to high performance in terms of developing designs within budget and on time, and able to meet a broad array of interests and preferences? This paper reports our findings.

In sum, we will argue that a commons organization can be an advantageous way to organize design work for capital assets with a high degree of design-choice interdependence that also impinge on many heterogeneous groups. As indicated, this situation is endemic to infrastructure projects that are central to the socio-economic development of modern societies. In a design commons organization, producers and funders share design rights with knowledgeable stakeholders, such as users, in order to acquire valuable information. The information thus acquired allows the final design to better address collective needs-inuse, and importantly, it cannot be obtained in any other way (e.g., via consultation, observation or statistical analysis). In the best of circumstances, the output of a robust design commons organization is a timely and makeable design for a long-lived capital asset that people with heterogeneous preferences can both share and afford.

Our study yields four contributions to a better understanding of the relationship between design structure and organization structure. First, violations of simple mirroring can serve to bring into the design organization important knowledge about subsequent use patterns. Specifically for artifacts with a high degree of design-choice interdependence that must be shared in use, a commons organization can strike a balance between the provision of design-relevant information and collective action problems leading to design failure. Second, collective action problems inherent in the design commons approach can be mitigated by setting up robust governance rules and practices. Third, in addition to robust governance, flexibility in the design itself can contribute in a major way to the success of the design organization. Fourth, the design commons form of organizing is likely to increase ex post user satisfaction as well perceptions of legitimacy of the design process, but conversely it can also lead to more 
conservative, less innovative designs being selected and to a more unequal allocation of resources than would arise in a more centrally managed and hierarchical organization.

In the remainder of this paper, we first locate Ostrom's work in relation to interorganizational collaboration theory and the economic theories of relational contracts and property rights. Then, in a theoretical section, we develop the concepts needed to apply commons theory to design organizations, explaining when and why a design can be viewed as a common pool resource, and how collective action problems increase the risk of design failure. Next, we describe our research setting, data, and methods. In the analytic section, we explain how the Council set up the school design organization and we evaluate its robustness using Ostrom's criteria. We conclude by arguing that the advantage of the design commons form of organizing in general rests on its ability to solve a tricky provision-of-information problem at low cost while containing collective action problems by means of social norms and context-sensitive rules.

\section{RELATED LITERATURE}

Ostrom's theory of polycentric organizations and commons governance is related to theories in other fields, specifically the theory of interorganizational collaboration (Schelling 1960, Raiffa 1982, Gray 1989, Pitsis et al. 2003, Ansari et al. 2013), the economic theory of relational contracts (Poppo and Zenger 2002, Baker et al. 2002, Gibbons and Henderson 2011), and property rights theory (Gordon, 1954, Libecap 1989). In a brief space, it is impossible to highlight all of the many points of connection between these different large bodies of work. But it is fair to say that interorganizational collaboration theory tends to focus on the negotiating process - the phases, options, tactics, formal rules and protocols, as well as the role of external parties (courts, arbitrators, and mediators) in settling disputes. In contrast, Ostrom's commons theory focuses on the efficacy of social norms, the rules of governance, and the goodwill generated by face-to-face interactions. Negotiations occur in all commons organizations, but the emphasis of her theory is not on negotiating and collaborating per se but on the rules that structure the claimants' interactions and reward or sanction their behavior. 
The economic theory of relational contracts considers the structure of agreements that do not require enforcement by a third party such as a court. Agreements between self-interested agents can be selfenforcing if the value of continuing to cooperate is higher (to all parties) than the value of defecting or reneging (Baker et al. 2002, Gibbons and Henderson 2011). Participants in a commons organization must believe that staying within that organizational framework, with all its rules, is more advantageous than leaving. But such organizations in general cannot be reduced to simple games of tit-for-tat. Thus, Ostrom includes relational contracts in her theory but her work is focused more on the practical design of a robust commons than on modeling the phenomena in terms of a small set of formal properties.

Like Ostrom, some property rights theorists have focused on common pool natural resources that demonstrably cause conflicts of interest hence collective action problems. Weakly defined or poorly enforced property rights are known to hinder the efficient use of resources (Libecap 1989, Wiggins and Libecap 1985, Alston et al.1985). Both the commons and property rights literatures agree on the reasons why claimants struggle to cooperate, highlighting the number and heterogeneity of the parties involved, information asymmetries, and conflicts over value distribution. But scholars working in the property rights tradition focus on law and/or formally negotiated contracts as the "solution" to collective action problems. In contrast, scholars working in the commons tradition highlight the role of socially-embedded local organizations and bottoms-up rule-making. Thus, although property rights theory and commons theory focus on the same phenomenon, and the parallels are suggestive, up to now, the relationship between the two literatures has hardly been explored. (Klein et al. 2011, is a recent and notable exception.)

\section{THEORY}

In this section, we draw on the extant literature to show how and when designs can be viewed as common pool resources, which in turn can be subject to commons governance.

\section{Background: A Taxonomy of Goods}

Economists typically array goods along two dimensions: (1) subtractability (also known as rivalry) 
and (2) excludability. A subtractable good is one for which consumption or use by one claimant reduces the flow of benefits to others. An excludable good is one for which it is relatively straightforward to limit access by others than the owner, either by physical means or through property rights. In the lexicon of public economics, a "pure" private good is both subtractable and excludable. Examples include chocolate bars, personal computers, and family homes. A "pure" public good is non-subtractable and nonexcludable. Examples include sunsets, parks without fences, and public roads. A "club" good is nonsubtractable, but excludable. Examples are parks with fences, private schools, and turnpikes. Finally, a "common pool resource" is subtractable and non-excludable. Examples are fish in the ocean, trees in an open forest, and books in a public library.

In natural language, the word "commons" refers to a resource shared by a group of people (Hess and Ostrom, 2007). However, in the academic literature, the word is used in two distinct ways, which can be a source of confusion. In legal scholarship, a commons is a property rights regime in which some goods are made freely available to all on a non-discriminatory basis (Frischmann, 2012). In contrast, in Ostrom's commons theory, a commons is an institutional setting in which a subtractable and non-excludable resource is managed collectively by local claimants, as opposed to hierarchically by government bureaucrats or private property owners. Thus to correctly apply Ostrom's principles, we must show when and why designs can be both subtractable and non-excludable. We take up the issue of subtractability first.

\section{Subtractability}

Subtractable goods are also known as "rival" goods. ${ }^{2}$ Designs are often cited as classic examples of "non-rival" i.e., non-subtractable goods, because the recipes, blueprints, and programs that go into a design can be copied and used by an unlimited number of people (Cornes and Sandler 1986; Romer 1990; Lessig 2001; Hess and Ostrom 2007). In a strict, technical sense, the "consumption" of a design by one

${ }^{2}$ In the economics of public/private goods, the terms "subtractable" and "rival" have the same meaning. Scholars studying natural resources, including Ostrom, generally use the term "subtractable." Scholars studying knowledge and intellectual property, e.g., Romer (1990), generally use the term "rival." We have opted to use Ostrom's terminology. 
person does not leave less design to be consumed by others, hence designs can be seen as quintessentially non-subtractable (cf. Romer 1990, Baldwin and Clark 2006).

Although designs are not subtractable, choices made in the course of the design process are subtractable from the perspective of the choosers. Design choices specify the structure of artifacts in terms of both form and materials. An artifact cannot have two forms at the same time: for example a building cannot be both square and round. Thus one design choice invariably rules out others. This fact alone would not be a problem if all claimants had identical preferences and beliefs. But when claimants have different priorities, one person's choices will preclude another's, thereby diminishing the value of the design for the second claimant. In effect, every choice made in a design process leaves fewer choices for others to make.

Design structure affects the degree of subtractability of design choices. In some cases, the individual design decisions are highly interdependent, and each choice affects many others. Such designs are called "integral" (Fine 1998). Conversely, if a design is highly "modular," then decisions in different modules will be independent of one other. In Herbert Simon's words, the design (and design process) will be "near-decomposable" (Simon 1962, 1981). As long as different agents care about different modules, a choice made by one will not take away (important) choices from the others. In this sense, modular design choices are less subtractable than integral design choices.

A tight budget increases the interdependency, hence the subtractability, of design choices. Given a fixed budget, what is spent on one feature cannot be spent on others, and claimants with different priorities must perforce compromise. An increase in the designed artifact's longevity also amplifies the subtractability of design choices. The claimants' understanding that some design choices will stay with them for decades makes it harder for them to give ground when negotiating design trade-offs.

We now consider the issue of excludability.

\section{Excludability}

Excludability refers to the ease with which potential claimants can be prevented from accessing the 
resource. While subtractability is largely determined by physical properties of the resource in relation to its consumption (is the resource depleted by consumption), excludability is determined by a combination of physical protections and property rights. Thus while the degree of subtractability of a good is hard to change, its excludability can be greatly affected by human actions (such as locking a door) as well as laws, social norms and conventions (such as patents and rights of privacy).

As with all information goods, property rights and secrecy can be used to exclude unauthorized parties from using a design. Designs are thus generally deemed to be partially excludable (Romer, 1990). In the case of the Manchester schools, the blueprints could be viewed by anyone interested in seeing them, but they could not be legally reused without the Council's authorization.

In contrast, the design choices for each school had low excludability although they were not open to everyone. Various national government departments had formal design rights because they were either supplying funds or setting standards. Likewise, various Council departments had design rights because they were the recipient of funding, responsible for school performance, or had planning authority. The architects and builders could not be excluded from the process because the Council had limited technical capabilities in-house. However, the Council had the right to decide who else (if anyone) would have design rights. It chose to share rights with the schools' faculties (but not with parents, pupils, and local communities). Once the Council announced this choice, the schools' faculties could not be excluded unless the Council went back on its word (which would have had negative political repercussions).

In the case of natural resources, the more agents with rights to the resource and the more heterogeneous their preferences and beliefs, the more likely it is that the group will fail to reach an efficient outcome (Libecap, 1989; Ostrom 1990). The same is true for designs. Design failures occur when the design organization fails to arrive at a good design in a reasonable amount of time. One possibility is that the participants will fail to reach a consensus through impasse (claimants yielding little from their initial positions), or iteration (endless cycling through various alternatives that satisfy no one). Alternatively, the quality of the final design may be low because of holdup (one or a few groups blocking 
progress until their demands are satisfied), optimistic bias (claimants settling on a design beyond their means), or excessive compromise that yields an unworkable, impractical, unwieldy, or inadequate result.

As discussed above, building design choices are generally held to be quite interdependent, hence the mirroring hypothesis suggests that building design organizations should exclude all but a minimal core set of decision makers from direct participation in the process. (Other stakeholders may be consulted, but should not have control over final decisions.) In fact, many architectural firms follow this practice (cf. Yoo, Boland and Lyytinen, 2006, on the architect Frank Gehry's organization). The world-famous architect Renzo Piano put it this way: "You have to listen but you don't have to be obedient" (Jacobs, 2013).

Thus, in terms of both property rights theory and the mirroring hypothesis, the Council seems to have been courting design failure when they included the school faculties in the design process and gave them veto power over final designs. Ostrom, however, offers a more optimistic view of the Council's action. Robust commons organizations, she argues, can deal effectively with subtractable and nonexcludable goods by creating and enforcing context-sensitive rules to avoid collective action failures. By studying the practices of successful and unsuccessful commons organizations, she sought to infer the principles associated with success. After we explain our data and methods, we will apply her principles to the Manchester school design organization.

\section{RESEARCH SAMPLE, DATA, AND METHODS Sample}

The $£ 450$ million Manchester Building Schools for the Future (BSF) program was part of a $£ 45$ billion national program to rebuild or refurbish all the government-funded high schools in England. The national program had three key stipulations: 1) the designs of the school buildings should be innovative and "transformative," 2) fixed budgets would be set by formula; and 3) timescales were rigid. Hence, if a project exceeded the budget or ran late, the local authority had to foot the bill or see the scheme cancelled. 
Our research focused on a sample of six school design projects that were representative of the "first wave" of the school-building program in Manchester which included 11 projects. All of the schools were either operating in dilapidated facilities and/or had scored low in national league tables. ${ }^{3}$ Notwithstanding these challenges, all of the schools had received positive evaluations from Ofsted (the Office for Standards in Education, Children's Services, and Skills), which regulates and inspects schools. The Ofsted evaluations were viewed as evidence of the competence and dedication of the schools' faculties.

With this assurance, the Council chose to adopt the design commons approach across the board:

We ... could sack the head and replace heads of faculties, but that wouldn't be democratic. We don't work that way. ... We work on the basis [that] these people ... [are] capable, they're there to improve attainment. If they become embattled and you give them a building with no choice, that doesn't empower people to deliver better results. [Council senior manager]

Against this homogeneous backdrop in terms of government mandates and design approach, we purposely formed our sample to be diverse and polarized, as recommended for process-focused inductive studies (Siggelkow 2007). Specifically, we sought to include schools with faculties that agreed with the national transformation agenda (according to Council interviewees), disagreed, and had mixed feelings. We also sought to create a sample that reflected the demographic and institutional heterogeneity of Manchester schools along three dimensions: 1) secular vs. faith-based, ${ }^{4}$ 2) multi-racial vs. homogeneous student bodies, and 3) free-standing vs. co-located with a community center or Special Educational Needs (SEN) school. Table 1 provides an overview of the six schools in the sample.

\section{TABLE 1- DESCRIPTION OF SCHOOLS IN THE SAMPLE}

\begin{tabular}{|l|l|l|l|l|}
\hline School & Type & Socio-economic context & $\begin{array}{l}\text { Unique features of } \\
\text { the school }\end{array}$ & $\begin{array}{l}\text { Ofsted assessment of overall school } \\
\text { performance: categorical and qualitative }\end{array}$ \\
\hline Abraham & $\begin{array}{l}1200 \text {-place } \\
\text { comprehensive }\end{array}$ & $\begin{array}{l}\text { Multi-racial, } \\
\text { significantly deprived } \\
\text { area; 84\% of pupils } \\
\text { come from minority } \\
\text { ethnic groups }\end{array}$ & $\begin{array}{l}\text { Mainstream school } \\
\text { co-located with } \\
\text { community center, } \\
\text { and with Special } \\
\text { Educational Needs } \\
\text { (SEN) school in } \\
\text { wave 2 }\end{array}$ & $\begin{array}{l}\text { Ghis is a good school with a range of outstanding } \\
\text { features serving its community extremely well.... } \\
\text { quality of teaching and learning is good. }\end{array}$ \\
\hline
\end{tabular}

\footnotetext{
${ }^{3}$ Every year the government produces league tables for secondary schools based on the results of the previous summer's exams.

${ }^{4}$ Faith-oriented schools are state-funded but voluntarily aided by a religious organization that owns the school's land.
} 


\begin{tabular}{|c|c|c|c|c|}
\hline Gorton & $\begin{array}{l}900 \text {-place } \\
\text { comprehensive }\end{array}$ & $\begin{array}{l}\text { Extremely deprived and } \\
\text { ethically diverse area; } \\
\text { over } 50 \% \text { of the pupils } \\
\text { are from minority ethnic } \\
\text { groups; English is } \\
\text { additional language for } \\
1 / 3 \text { of pupils } \\
\end{array}$ & $\begin{array}{l}\text { Mainstream } \\
\text { school co-located } \\
\text { with 110-place } \\
\text { SEN school }\end{array}$ & $\begin{array}{l}\text { Satisfactory [mainstream] } \\
\text { Teaching is good... students' outcomes in terms of } \\
\text { learning and achievement are satisfactory } \\
\text { Outstanding [SEN] } \\
\text { School has profound and beneficial impact on } \\
\text { students and their families... students' personal } \\
\text { development and achievement are outstanding }\end{array}$ \\
\hline Newall & $\begin{array}{l}900 \text {-place } \\
\text { comprehensive }\end{array}$ & $\begin{array}{l}\text { Extremely deprived area; } \\
40 \% \text { of the pupils } \\
\text { potentially } \\
\text { disadvantaged and } \\
\text { vulnerable to } \\
\text { underachievement }\end{array}$ & \begin{tabular}{|l|} 
Co-located with \\
community center; \\
school houses a \\
center for pupils \\
with severe learning \\
difficulties
\end{tabular} & $\begin{array}{l}\text { Outstanding } \\
\text { The care, guidance, and support provided are } \\
\text { outstanding.... school team has proven track record } \\
\text { of turning around disaffection and breaking cycles } \\
\text { of underachievement, low self-esteem, and low } \\
\text { opportunity }\end{array}$ \\
\hline Matthews & $\begin{array}{l}\text { 1100-place } \\
\text { faith-based }\end{array}$ & $\begin{array}{l}\text { Relatively disadvantaged } \\
\text { area; } 35 \% \text { of students } \\
\text { eligible for free school } \\
\text { meals; } 90 \% \text { of students } \\
\text { are from a white British } \\
\text { background }\end{array}$ & $\begin{array}{l}\text { Free-standing } \\
\text { school }\end{array}$ & $\begin{array}{l}\text { Satisfactory } \\
\text { School has a number of significant strengths, } \\
\text { particularly in the quality of care, guidance, and } \\
\text { support offered to its pupils; teaching and learning } \\
\text { are satisfactory }\end{array}$ \\
\hline Paul & $\begin{array}{l}\text { 900-place faith- } \\
\text { based }\end{array}$ & \begin{tabular}{|l|} 
Socially and \\
economically \\
disadvantaged area; large \\
influx of non-native \\
English-speaking \\
students
\end{tabular} & $\begin{array}{l}\text { Mainstream school } \\
\text { co-located with 110- } \\
\text { place SEN school }\end{array}$ & $\begin{array}{l}\text { Satisfactory [mainstream] } \\
\text { Pupils' personal development is satisfactory... } \\
\text { quality of teaching and learning is satisfactory... } \\
\text { quality of care, guidance, and support is good } \\
\text { Outstanding [SEN] } \\
\text { Students leave as confident and well-rounded } \\
\text { because their personal development is exceptional }\end{array}$ \\
\hline David & $\begin{array}{l}850 \text {-place } \\
\text { faith-based }\end{array}$ & \begin{tabular}{|l|} 
Proportion of students \\
eligible for free meals \\
below average; over $99 \%$ \\
native English-speaking; \\
students' academic \\
achievement well above \\
national average
\end{tabular} & $\begin{array}{l}\text { Free-standing } \\
\text { school; serves a } \\
\text { wide geographical } \\
\text { area (both city and } \\
\text { suburbs) }\end{array}$ & $\begin{array}{l}\text { Very good } \\
\text { The school aims to meet the needs of students who } \\
\text { would have gone to the independent sector were the } \\
\text { school not to achieve high examination } \\
\text { performance...pupils' spiritual, moral, social, and } \\
\text { cultural development is very good }\end{array}$ \\
\hline
\end{tabular}

\section{Data collection}

To improve the accuracy of our data and the robustness of the conceptual insights (Jick 1979), we triangulated several data sources (Miles and Huberman 1984: 234). The fieldwork started in the spring 2008 and spanned the following three years. The first author conducted 33 formal interviews (each lasting one to two hours), including school staff (\#18); council staff (\#10), and consultants (\#5). He also took guided tours of both the old and new facilities, and reviewed archival data internal and external to the Manchester BSF program. The internal documents included school vision statements, design briefs, and drawings; project reports; council newsletters and press releases; schools' newsletters and Ofsted reports; and articles in the local press. The external sources included the governmental websites of the Department for Education, teachernet.com, and Partnerships for Schools (PfS); design manifestos published by UK architectural professional bodies; school design standards; and other official reports. We used the 
Manchester documents to analyze the design outcomes and to cross-check the respondents' accounts of the operational rules and processes. We used the external websites and documents to cross-check the respondents' accounts of higher-level governance.

A senior Council official was our key contact. He introduced us to other Council members who, in turn, introduced us to the project staff. For the purposes of internal validation and to overcome inherent biases, we called the schools without introduction to arrange the interviews. We managed to interview the senior teachers participating directly in the design process, typically the head teacher, ${ }^{5}$ deputy head, and some heads of faculties. ${ }^{6}$ All interviews were recorded and transcribed. We were not requested to sign any confidentiality forms, provide anonymity, or run quotes by the interviewees.

\section{Data analysis}

In our research, we aimed to develop a broad, contextualized understanding that would inform our core questions (Eisenhardt 1989): What was the motivation to misalign design and organization structures? How did the misalignment affect project performance? What factors assisted or detracted from collective decision-making? To investigate these issues, we employed an iterative research process (Miles and Huberman 1984), and we embedded units of analysis in our interview structure in order to yield more generalizable and robust insights (Yin 1984). Specifically, we focused on two key sets of collective design choices and the processes surrounding them: 1) choices to design in or out innovative elements in the buildings; and 2) choices about design trade-offs in the face of fixed and tight budgets.

We started our analysis with a set of high-level codes (Miles and Huberman 1994) that emphasized the teachers' local knowledge and how that knowledge influenced their contribution to the design. Then, as we learned about the interaction between the Council and schools, we began to consider the notion that the design-in-process could be considered as a common pool resource, and that a polycentric design commons organization had been created. At that point, we used Ostrom's (1990) framework to guide

\footnotetext{
${ }^{5}$ A "head teacher" (of a mainstream or special education needs school) is the same as the "principal" of a U.S. secondary school. ${ }^{6}$ A "head of faculty" supervises the curriculum and teachers in a given subject area, for example, math, history, science.
} 
further data collection and analysis, often engaging in follow-up interviews to fill gaps in the data and to seek answers to questions that arose late in the analysis. Interviewing multiple individuals at different times helped to develop a more reliable theory (Miller at al. 1997). After an initial manual pass sifting through raw data and populating the sensitizing categories with data excerpts, we verified the coding by enlisting the help of a second scholar with knowledge of the research design. We continued to cycle between data and theory, refining the cross-case comparisons and searching for regularities (Langley 1999). In this process, some codes became more salient (e.g., low excludability, high subtractability, and design flexibility) while others were dropped (e.g., lead users).

\section{ANALYSIS: ROBUSTNESS OF THE CREATED COMMONS}

Based on her study of success and failure in natural resource commons organizations, Ostrom (1990) proposed a set of eight design principles that can be used to gauge the "robustness" of a commons organization. A number of studies have shown that these principles are correlated with the success of natural resource commons organizations, although no single principle is either necessary or sufficient (Cox et al. 2010). In this section, we use these criteria to assess the robustness of the Manchester school design organization. The principles are listed with brief descriptions in Table $2 .{ }^{7}$ We discuss how well the Manchester organization conformed to these principles in subsections below.

\section{TABLE 2 - DESIGN PRINCIPLES FOR A ROBUST COMMONS}

\begin{tabular}{|l|l|}
\hline Principle & Explanation \\
\hline $\begin{array}{l}\text { 1. Nested "polycentric" } \\
\text { enterprises }\end{array}$ & $\begin{array}{l}\text { Commons are parts of larger systems, with many centers of power, organized in } \\
\text { multiple layers of nested enterprises. }\end{array}$ \\
\hline 2. Clearly defined boundaries & The boundaries of the commons and its rightful participants are clearly defined. \\
\hline $\begin{array}{l}\text { 3. Proportionality of benefits } \\
\text { and costs }\end{array}$ & $\begin{array}{l}\text { Rules affecting appropriation and provision are "congruent." In other words, for } \\
\text { each participant, the benefits of participation are roughly proportional to the } \\
\text { costs, and those who pay the most, receive the most. }\end{array}$ \\
\hline $\begin{array}{l}\text { 4. Collective-choice } \\
\text { arrangements }\end{array}$ & Individuals affected by rules can participate in modifying them. \\
\hline 5. Monitoring & $\begin{array}{l}\text { Monitors who can audit the condition of the resource and the participants" } \\
\text { behavior are responsive and accountable to the participants. }\end{array}$ \\
\hline 6. Graduated sanctions & $\begin{array}{l}\text { Participants who violate rules are likely to be assessed graduated sanctions. Small } \\
\text { and first offenses are identified, but not severely punished. }\end{array}$ \\
\hline
\end{tabular}

${ }^{7}$ Ostrom (1990) presents the principles in a slightly different order, placing "clearly defined boundaries" first and "nested polycentric enterprises" last. 


\begin{tabular}{|l|l|}
\hline $\begin{array}{l}\text { 7. Conflict-resolution } \\
\text { mechanisms }\end{array}$ & $\begin{array}{l}\text { Participants have rapid access to low-cost local arenas to resolve conflicts. } \\
\text { Ideally, conflict resolution should be face-to-face. }\end{array}$ \\
\hline $\begin{array}{l}\text { 8. Recognition and non- } \\
\text { interference by authorities }\end{array}$ & $\begin{array}{l}\text { The rights of participants to manage the commons, change local rules, monitor } \\
\text { and sanction peers, and resolve their own conflicts are not challenged by } \\
\text { government authorities. }\end{array}$ \\
\hline
\end{tabular}

Source: Adapted from Ostrom (1990), pp. 90 and 180.

\section{Nested "polycentric" enterprises}

A commons organization exists within a larger context and is related to other institutions in the surrounding society. In research in California, the Philippines, and Canada, Ostrom found that the larger system could support or undermine a commons organization in various ways. She theorized that the levels of rule-making should be nested, with higher-level organizations, like state or national governments, spanning lower-level entities that are responsible for day-to-day operation and governance. If the lowerlevel decision-makers stay within their constitutions, the higher levels should respect their decisions. Ostrom called this form of organization "polycentric" because there are many centers of legitimate decision-making. According to Ostrom's research, commons organizations fail on this criterion when law enforcement is compromised or corrupt, when higher-level rule-making authority is contested, when conflicting rules are established by competitive agencies, or when a controlling bureaucracy (or private owner) interferes with (or fails to recognize) local self-governing organizations (Ostrom 1990, pp. 143181).

On the surface, a polycentric commons organization resembles a classic firm or bureaucratic hierarchy making use of delegated authority (March and Simon, 1958). But, relative to these other ways of dividing work and integrating effort (Puranam et al. 2011), commons organizations are more consensual at all levels, and generally allow greater flexibility at the local level. Also the operational level of the commons (where most of the work gets done) generally relies at least in part on voluntary participation and uncompensated contributions of effort. Thus some of the polycentricity of a commons organization can be traced to the credibility and reassurance it offers to volunteers that their time and effort will not be spent in vain. In this respect, commons organizations are akin to some of the so-called "new" organizational forms, such as open source communities (von Hippel and von Krogh, 2003; Baldwin and Clark 2006; 
O’Mahony 2007; Puranam et. al. 2011). ${ }^{8}$

The highest level of rule-making in the school design commons was the national government, which supplied the money. Each school was given a fixed budget, determined by a formula that considered the number of pupils and the location. In addition, a critical justification for the national program was the idea that innovative school buildings could "transform" learning (DfES 2003). Innovative pilot projects promoted open floor plans and featured centers for e-learning and environmental discovery, state-of-theart ICT classrooms, movable pods, play decks, mobile classrooms, and themed learning centers. Such elements did not come at low cost, however, thus from the beginning, there was tension between the inflexible budgets and the aspiration to encourage innovative, "transformative" designs.

The next level of organization was the "local authority," in this case the Manchester City Council. Its top level is the "Executive", made up of nine elected councilors. An apolitical team of Directors led by a chief executive implements Council policy, supervises the staff and reports to the Executive. The school projects were supervised by the Council's Capital Programs group, which had longstanding relations with two design-build consortiums. Staff from Capital Programs were assigned to project teams to oversee the school designs and supervise the work of the architects and builders. In addition, to help deliver on the "education vision" described in its bid for funding, the Council appointed an internal Learning Transformation Team (LTT) made up of three former teachers who were familiar with the national transformation agenda and criteria. As is typical of a "boundary-spanning broker" (Tushman 1977), the LTT served as a bridge between the Capital Programs staff and the schools' faculties.

Finally, each school project had a designated "design steering group" made up of the schools' governors and faculty (the head or deputy head teacher, heads of faculty), Capital Programs and LTT staff, and private contractor employees. Construction on a given school could start only once the steering group signed off on the detailed plans. The "rules of the game" and the timetable were explained in a

\footnotetext{
${ }^{8}$ However, the modular structure of open source code serves to dampen collective action problems, hence arguably makes the process of volunteering less risky (Baldwin and Clark, 2006; MacCormack et al. 2012).
} 
School Starter Pack given to each school at the launch meeting for the project.

The steering groups met roughly once every two weeks for approximately a year. Meetings generally took about three hours. These closed meetings were organized by the Council but normally took place at the school. In each steering group, a core of about 10 people regularly attended the meetings. The steering groups for different schools did not meet with one another, although some Council staff and contractors belonged to several groups and individuals such as head teachers inevitably talked to their counterparts in other professional forums.

With respect to the criterion of nested, polycentric enterprises, we judge the Manchester design commons organization to be robust. As depicted in Figure 1, a nested hierarchy of decision-makers and rules defined the scope, participants, and procedures of the design process for each school. Higher levels of the organization crafted superordinate rules that lower-level participants worked within, bent, or refined. Within the arena defined by the rules, steering group members could exchange ideas and information and search for trade-offs and compromises.

\section{FIGURE 1 - SCHEMATIC REPRESENTATION OF THE DESIGN ORGANIZATON}

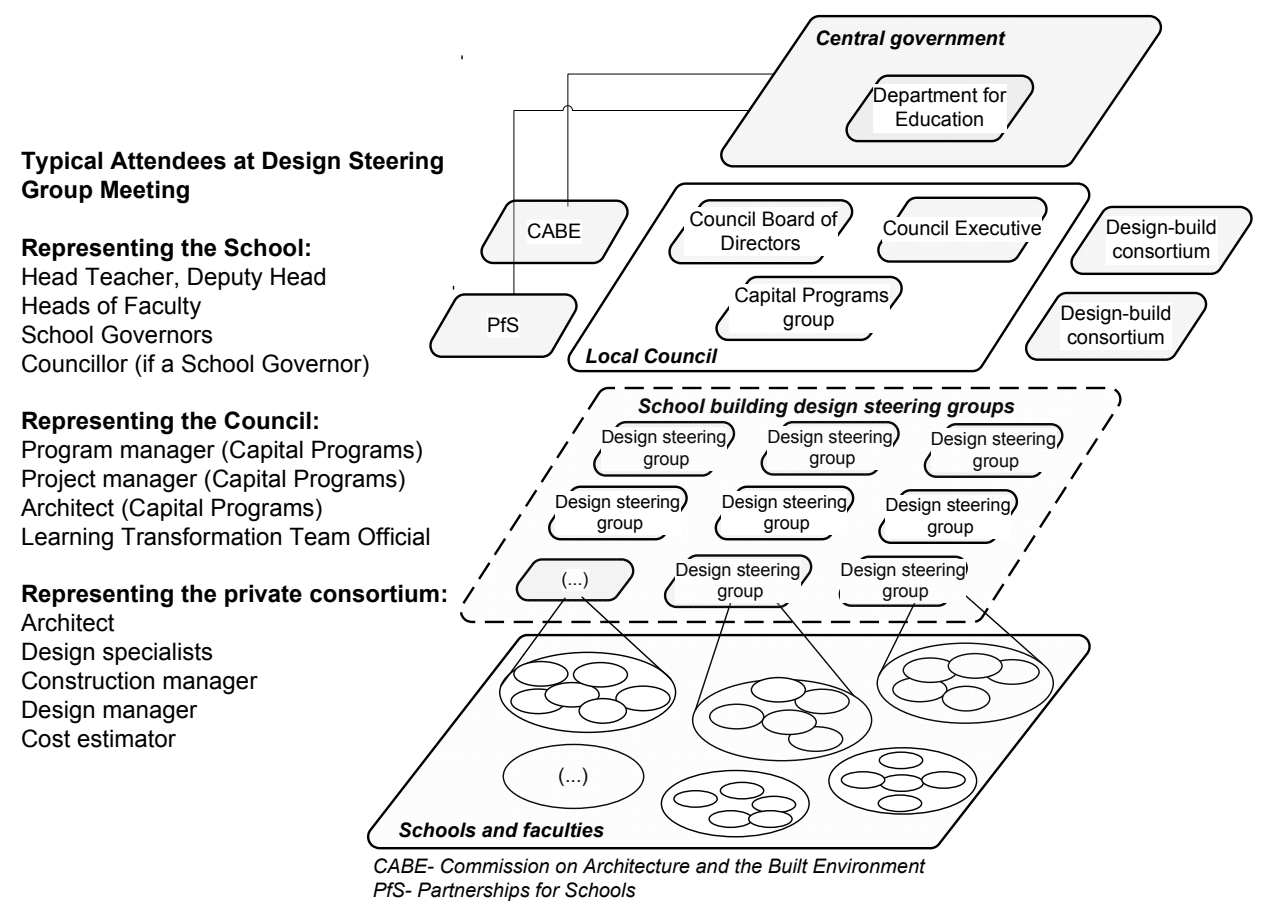

Source: Compiled by the authors from interviews and Council documents. 


\section{Clearly defined boundaries}

According to Ostrom, a robust commons organization needs clear boundaries specifying who has the right to participate and who has the responsibility to maintain the common pool resource. Boundary demarcation helps to avoid free riding and allows those within the boundaries to develop greater trust, reciprocity, and willingness to cooperate (Ostrom 2005). In the Manchester design commons organization, most of the substantive design work was done by the steering groups in closed meetings. Notably other parties such as parents and pupils were not invited to attend these meetings.

The steering groups went one step further in demarcating the boundaries of the different participants. The Council staff proposed and all steering groups agreed (although some were unhappy about it) that the staff should keep the upper hand in resolving conflicts over technical construction issues. The staff cast the Council as "the landlord" that had to pay for building maintenance and, in this role, it ruled that all schools would have open ceilings to allow better access to pipes, wiring, and ventilation systems. Some teachers and school staff disliked the aesthetics of exposed plumbing and electrical systems ("It's the maddest idea," commented one deputy head), but others had no issues at all ("We'll probably blink them out after a few days," noted another head).

As a quid pro quo, the Council staff offered to defer to the schools in conflicts over innovations that might interfere with education. Some schools, like Gorton, were fully on board with the national transformation agenda, but others were dubious or downright resistant. Some insisted that the proposed innovations - such as open floor plans - were not grounded in evidence, a key factor in facilitating the adoption of innovative ideas in complex institutional settings (Ferlie et al. 2005). Many also dismissed examples in which open plans had worked, arguing, as one LTT member reported, that Manchester's "reality was a far cry from schools in leafy Copenhagen neighborhoods.",

By far the most resistant school was David, which also had the highest academic performance according to the league tables. Here the teachers categorically dismissed all suggested innovations. The

\footnotetext{
${ }^{9}$ Hellerup school in Copenhagen is an open-plan school that was often cited as a model by proponents of the transformation
} agenda. See, for example, CABE (2009). 
deputy head put it, "The Heads of Faculty met, we had a clear vision of what we wanted, and we stuck to that." This attitude created a dilemma for the Council staff, given the Council's commitment in its bid to the national government for funding to promote innovative designs.

Tensions notwithstanding, our evidence suggests that the boundaries of the design commons were well defined. Rights to participate in the design process and the responsibility to arrive at a workable design on time and within budget were vested in the steering groups. Membership in the steering groups was clearly delineated and the effective working groups were relatively small.

\section{Proportionality of benefits and costs}

For a commons organization to succeed, the benefits to each participant need to be proportional to the investment (Ostrom 1990). This was the case in our focal setting. For the Council, investing resources to arrive at innovative building designs was clearly worthwhile because the school-building program offered a one-time opportunity to modernize the city's dilapidated schools with national government money. The value proposition for the builders was also straightforward: they were offered limited commercial gains with limited risk. And because the builders' profit margins were slim, they had strong incentives to participate actively in the design process to ensure that designs were consistent with the budget and schedule.

For their part, the schools gained design rights by virtue of their participation in the steering groups, but they were asked to dip into their operating budgets to free staff to engage in the design process and attend (many) meetings. Consistently, the schools estimated their input at more than 1,000 staff hours spread over one year, with larger schools reporting a figure closer to 1,500 hours. Most schools found it frustrating to be called upon to supply valuable inputs "for free". But the chance to get the design "right" was a benefit that was valuable enough to entice all of them to participate in the process from start to finish.

On the whole, the Manchester design commons appears to have done a good job in providing all participants with benefits that exceeded the costs incurred. Evidence of this can be gleaned from the fact 
that all participants stayed involved in the process until its natural conclusion.

\section{Collective-choice arrangements}

Another criterion for a robust commons organization is that individuals affected by rules can have a role in modifying them. On this dimension, the school design commons does not fare so well. Rules on the budget, building standards, and innovation were imposed by the national government, and were not subject to modification without great effort. Other rules on participation, the timetable, and the choice of the private contractor were established by the Council staff.

The schools complained that the Council staff systematically pushed back attempts to modify the rules. The staff replied that, while they listened to all voices, they had to obey the rules set by their Directors. Indeed, some schools tried to circumvent the rules by using their political connections to find out if there was any slack in the budget or to lobby for their choices. As one SEN head explained, "I wouldn't accept everything the [Council] team comes out with. We've got routes to challenge them. It's using the politics back. We know the political and senior hierarchy of the teams." In at least one case, the Council also used political backchannels, as the Abraham head described, "Our governing body was asked by the Council governor to approve a scheme we weren't recommending. Luckily, it was turned down, [but] it was a dangerous time." (The case of Abraham is described in greater detail below.)

For the most part, however, the parties used steering group meetings to search for ways to bridge their differences while staying within the Council and nationally mandated rules. The one important exception was in the realm of budget overrides. With the Council's compliance and even encouragement, a budget constraint could be relaxed if the school funded the excess.

The case of Abraham illustrates another way in which rules were relaxed in response to pressure from local participants. Abraham was unique in that the first design process (2007) failed because of a fundamental disagreement over the minimum footprint of the building. As the head explained, "We were told we were not cooperating; we were in limbo. I then wrote [the Council] a hard letter saying that I wasn't being uncooperative. I was actually doing the [Council's] job for them, to safeguard the 
youngsters' needs and make sure they had a viable school for the future." Thus, the design commons organization arrived at an impasse, and Abraham's building was not included in the first wave of construction. Two years later, the parties agreed to co-locate Abraham with a SEN school, which increased its formulaic budget by $£ 2 \mathrm{~m}$. A new design process was begun in 2009; the parties were able to reconcile their disagreements; and a new school was built in 2010-2012. Relaxing the budgetary rules (and in Abraham's case, the timetable) was an important safety net for the commons organization. It allowed the steering groups to overcome the tensions inherent in the participants' conflicting goals. But it also created inequities across schools (discussed below).

\section{Monitoring}

Commons theory argues that those who monitor and audit the commons' conditions and participants' behavior should stay accountable to the participants. The design commons organization was not robust on this dimension. By and large, the monitors were responsible to the government rule-makers and not the schools.

First, the national government appointed the Commission on Architecture and the Built Environment (CABE) to monitor and control the innovative qualities of each school's design. During two "healthcheck sessions" that could last between three to four hours, members of CABE challenged each school's design and asked for justifications as to why some choices contradicted the government mandate. Money to fund construction would not be released until CABE gave the go-ahead.

Secondly, the Council Directors ruled that Capital Programs was the budget holder and that only its staff could give instructions to the private architects and builders. The Directors believed that these powers were needed to ensure that the designs stayed within budget. This was a tough rule because the national formula ignored the schools' argument that the trend towards personalized learning placed increased demands on space. As one deputy head remarked, "The funding methodology is based on a massively flawed formula that has been in place forever. ... Everyone knows these flaws but no one is going to do [anything].... It isn't fair.” 
Thirdly, the Council staff made the external architects and builders responsible for monitoring the designs' compliance with the national transformation agenda and for ensuring that the designs stayed within budget. In the steering group meetings, the architects and builders worked with the schools' representatives to express their visions and accommodate their priorities, using design flexibility (discussed below) to creatively reconcile conflicting priorities and beliefs. At least officially, though, these monitors were not accountable to the steering groups but to Capital Programs and the Council.

\section{Graduated sanctions}

In commons theory, sanctions are needed because people are heterogeneous. There will always be some individuals with a propensity to break rules if they believe they can get away with it (Ostrom 1990). But flagrant or widespread rule-breaking often triggers a vicious cycle of defection that can end in failure for the commons organization. Thus, monitoring and sanctions are necessary. ${ }^{10}$

Although this principle makes sense, we found it empirically difficult to make sharp distinctions between breaking rules, changing rules, and exercising rights. Relaxing budget constraints when schools are willing to make up the shortfall seems like a sensible rule change. When Abraham's head teacher, backed by his governing board, refused as a matter of principle to sign off on the design, that was an exercise of rights, not a rule violation per se. But the same action in a different context could be seen as holding up the process and demanding a bribe - a clear rule violation.

In addition to the formal rules imposed by the national government and the Council, the main informal rules were those of repeated private interaction, civility, and mutual respect. In the steering group meetings behind closed doors, sharp exchanges might have occurred but they remained private. At times, people issued threats to use political backchannels to overturn the process, but those actions were either ineffective or not carried out. (On the importance of face-to-face meetings in establishing and enforcing norms of reciprocity and trust, cf. Ostrom et al. 1994, Ostrom, 1998.)

\footnotetext{
${ }^{10}$ However, Ostrom (1990) argues that a system of graduated sanctions is best because it assures participants that rules are being
} enforced but initial penalties will not be unduly harsh. 


\section{7. versus 8. Conflict-resolution mechanisms versus recognition and non-interference by authorities}

We discuss these two criteria together because they ran in opposition to each another in our empirical setting. On the one hand, Ostrom argues, participants in a robust commons organization should have access to effective and timely conflict-resolution mechanisms. On the other hand, the participants' rights to devise their own rules should not be challenged by higher-level authorities (Ostrom 2005).

In the Manchester design commons organization, conflicts that could not be settled within the steering groups could be taken up to the Council Directors. In extreme circumstances (as in the case of Abraham), conflicts could be escalated to the Council Executive. Nevertheless, Council staff expressed frustration with the lack of a lower level of appeal. For reasons unrelated to the building program, the Council's post of Chief Education Officer (a position just below that of Director) remained unfilled throughout the program. One level up, the Council's Director of Children Services had limited time to get involved. To avoid delaying the process, some Council staff thought they had compromised too much. As one program manager remarked, "the teachers have been carrying all the cards, but they're not a client; they're a user. They need to be involved but shouldn't control. At the end of the day, it's Council funding."

Unsurprisingly, the participants from the schools disagreed with this view. Faced with tight and fixed budgets, school participants felt they were "always robbing Peter to pay Paul", as one SEN head exclaimed. They also pointed out that the Council rarely relaxed technical requirements even after debates suggesting that some design standards were out-dated or inadequate.

The presence of a Chief Education Officer would have implicitly put more power in the hands of the Council staff. This, in turn, might have undercut the autonomy of the steering groups, leading the schools to believe they had no real power in the process. Instead, within the space delimited by the rules, the steering group members had the power to bend the rules, devise compromises, and resolve their conflicts.

Also contributing to the robustness of the commons, the national government limited its interference with the design process and respected the lower-level design choices. Provided the designs were 
consistent with the school's vision, the "golden thread" as the Commission on Architecture and the Built Environment put it, the steering groups were allowed to produce traditional designs. This correspondence between the schools' preferences and the final designs contributed to the schools' overall satisfaction with the design process and outcomes (see the discussion of performance below). But we also observed instances where design flexibility (also discussed below) was critical in reconciling the divergence between the schools' preferences and the national transformation agenda.

\section{Overall assessment of robustness}

On balance, the school design commons organization appears to have been quite robust, as measured by Ostrom's criteria. The main fragilities were that 1) the local claimants had limited ability to change the high-level rules that were imposed from above by the national government and the Council, and 2) the monitors were accountable to the government and Council, not to the local claimants.

Given these fragilities, it is reasonable to question whether the Manchester school design organization was a "true" commons where higher authorities respected local autonomy and collective decision-making vs. a bureaucracy masquerading as a commons where disputes would be escalated back up the hierarchy and settled by higher authorities. The case of Abraham, discussed above, supports the contention that the organization was not a bureaucratic hierarchy in disguise. Recall that the Council project team tried to over-ride the school's veto by lobbying the school's governors to approve the design. The head teacher, having been granted design rights and with faculty behind him, was prepared to fight back - 'I would have to finish writing to everybody in the government...if it [the design] had been pushed forward', said the head. When push came to shove, the school's governors (who legally controlled the school's property, hence had to approve new construction) sided with the head teacher. For its part, the Council Executive did not press the issue further despite genuine worries that national funding could be lost. For better or worse, the Council had created ${ }^{11}$ a genuine commons organization subject to collective

\footnotetext{
${ }^{11}$ In Ostrom's research, there are other instances of commons organizations being created by interested outside parties. Cf. the
} ARTI/Cornell water management initiative in Sri Lanka (Ostrom, 1990, pp. 168-73) 
local rule. In this context disenfranchising the teachers was not a viable option.

In summary, within the steering groups, where most decisions were made, there was room to make genuine tradeoffs between the teachers' practical knowledge and the Council's commitment to the national government to create innovative buildings within fixed, tight budgets. Some of these tradeoffs took the form of pure compromise with each side giving up something to gain something else. But, as the next section describes, the architects also played a key role by making creative use of design flexibility.

\section{USING DESIGN FLEXIBILITY TO RESOLVE CONFLICT}

In a traditional setting, the commons organization manages a natural resource, and technologies are viewed as part of a static geophysical domain (Ostrom 2005). In our setting, the common pool resource is a design-in-process, that is, an artificial construct (Simon 1981). Hence, the technologies involved are not static, but subject to creative manipulation. Indeed, our research suggests that technological flexibility in the building designs was an important intervention (by the architects) that was used to reduce conflict within the commons organization. "We try to reconcile equals," said one architect. Or, as another commented, "It's a duty of care we've as professionals to ... find solutions that don't conflict."

At the crux of many recurring conflicts were different planning horizons, often a source of tension among participants in a commons (Ostrom 1990) or in infrastructure projects (Gil and Tether 2011, Gil et al. 2012). The schools would only endorse designs they deemed fit for the purpose on the opening day, but the Council staff knew that the schools would be in use for 50 years or more. At many schools, this conflict became acute around the issue of open floor plans. Council staff on the steering groups did not want to overrule the schools, and the Learning Transformation Team admitted there was little good data to support the effectiveness of open plans (Woolner et al. 2007). One program manager explained "There was little time to educate schools, and teachers weren't in the same wavelength. Some were in the dark ages. They thought they were the masters of the universe. They didn't want to be fettered."

To address this conflict, the architects proposed to use flexible steel-framed superstructures with long spans and large floor plates to create areas that could be reconfigured from a traditional layout into 
an open plan (and vice versa) at reasonable cost. Then, for the schools that rejected open plans, the architects proposed lightweight modular walls sitting on top of the floor rather than rigid load-bearing walls. For the schools with mixed feelings about open plans, they used retractable walls to create smaller spaces that could be recombined into large master classrooms. Finally, at all schools, they decoupled the air ventilation systems from the room layout by distributing multiple air-handling units on a dense grid, ensuring the provision of high-quality air irrespective of the wall locations.

Of course, these investments in flexible designs did not come at zero cost: the retractable walls and modular air ventilation systems were more expensive than conventional solutions. Cost notwithstanding, design flexibility turned out to be a crucial factor in avoiding impasses within the steering groups as they converged towards final designs. For schools that were eager to embrace innovations but were concerned they might not work, flexible solutions were reassuring because the building layouts could be cheaply reconfigured into conventional forms. As Gorton's assistant head summarized, "We're trying to pioneer something [the open plan] here; see if it works. If it doesn't in the end, it won't cost that much money to put doors on." At the other extreme, for a school such as David that categorically opposed innovation in building design, ${ }^{12}$ a flexible design reassured the Council that its commitment to the national transformation agenda was fulfilled to some degree. As the architect explained, "We responded to [David's] brief, but we gave them a building that carries this flexibility in its DNA. There are huge possibilities. They can knock walls down."

\section{ASSESSING THE PERFORMANCE OF THE DESIGN COMMONS ORGANIZATION}

In addition to analyzing the robustness of the design commons organization using Ostrom's criteria, we assessed its performance along three dimensions: 1) innovativeness, 2) participants' satisfaction with the process and the outcome, and 3) equitability. Our assessment of innovativeness was based on a quantitative breakdown of building space into traditional and non-traditional areas - open plans and non-

\footnotetext{
${ }^{12}$ Although David's faculty was conservative with respect to building design, the Council staff acknowledged that David was in the forefront in terms of pedagogical innovations.
} 
traditional layouts were the cornerstone of the government's plan to transform education through capital investment. Our assessment of satisfaction was based on a qualitative evaluation of the comments by the schools' leaders, Council staff, and private contractors. Finally, our assessment of equitability was based on the amount of extra funds (beyond the budget) that each school was able to apply to the project. The results are summarized in Table 3.

TABLE 3 - PERFORMANCE OF THE DESIGN COMMONS ORGANIZATION

\begin{tabular}{|c|c|c|c|c|}
\hline \multirow[t]{2}{*}{ Case } & \multirow[t]{2}{*}{ Innovativeness } & \multicolumn{2}{|c|}{ Satisfaction of the school leaders } & \multirow[t]{2}{*}{ Equitability } \\
\hline & & with the process & with the outcome & \\
\hline Abraham & $\begin{array}{l}\text { Traditional: } \\
\text { Science area: only } \\
\text { traditional labs (3); } \\
\text { other faculty areas: } \\
94 \% \text { traditional; } 6 \% \\
\text { master rooms }\end{array}$ & $\begin{array}{l}\text { Negative [wave 1]; Positive [wave 2]: } \\
\text { It [wave 1] was a very difficult, really } \\
\text { upsetting experience...I was bullied a } \\
\text { bit, but they [Council] couldn't get me } \\
\text { to agree to it. ...In wave } 2 \text { everyone } \\
\text { understood our point of view [Head] }\end{array}$ & $\begin{array}{l}\text { Positive [wave 2]: } \\
\text { In addition to basic accommodation- } \\
\text { we got } 95 \% \text { of that -we got } \\
\text { enhancements. It'll be a terrific } \\
\text { boost.... I feel very happy about it } \\
{[\text { Head ] }}\end{array}$ & $\begin{array}{l}\text { Privileged: } \\
\text { School used } £ 250 \mathrm{~K} \\
\text { in reserves to pay } \\
\text { for extra staff room } \\
\text { and all-weather } \\
\text { pitches }\end{array}$ \\
\hline Gorton & $\begin{array}{l}\text { Innovative: } \\
\text { Science area: hybrid } \\
\text { IT-equipped labs (6) } \\
\text { other faculty areas: } \\
52 \% \text { traditional; } 38 \% \\
\text { master rooms; } 10 \% \\
\text { open plan }\end{array}$ & $\begin{array}{l}\text { Positive: } \\
\text { It was a fantastic process. I was never } \\
\text { prepared for how much people would } \\
\text { listen to what I say ...I've been a teacher } \\
\text { for a long time. But single handedly, this } \\
\text { is the thing I'm most proud of [Assistant } \\
\text { Head] }\end{array}$ & $\begin{array}{l}\text { Positive: } \\
\text { The building is beautiful, absolutely } \\
\text { astonishing: the tall ceilings, the glass, } \\
\text { the transparencies [Assistant Head] }\end{array}$ & $\begin{array}{l}\text { Somewhat } \\
\text { privileged: } \\
\text { Additional funds } \\
\text { from co-location } \\
\text { with SEN school }\end{array}$ \\
\hline Newall & $\begin{array}{l}\text { Hybrid: } \\
\text { Science area: only } \\
\text { traditional labs }(7) ; \\
\text { other faculty areas: } \\
55 \% \text { traditional; } \\
45 \% \text { master rooms }\end{array}$ & $\begin{array}{l}\text { Moderate: } \\
\text { The process was as democratic as it } \\
\text { could be...but the figures were shrouded } \\
\text { in secrecy; if you're working together, } \\
\text { and we worked quite well, you should be } \\
\text { more transparent [Deputy Head] }\end{array}$ & $\begin{array}{l}\text { Moderate: } \\
\text { It's going to look really nice and } \\
\text { practical, but the school we're getting } \\
\text { will be slightly smaller than the } \\
\text { current school, which was never big } \\
\text { enough - which is crazy, isn't it? } \\
\text { [Deputy Head] }\end{array}$ & $\begin{array}{l}\text { Privileged: } \\
\text { School could afford } \\
£ 500 \text { K loan to } \\
\text { cover courtyard }\end{array}$ \\
\hline Matthews & $\begin{array}{l}\text { Hybrid: } \\
\text { Science area: } 3 \\
\text { 'super-duper labs' } \\
\text { as put by the Head } \\
\text { of Science; } \\
\text { other faculty areas: } \\
74 \% \text { traditional; } \\
18 \% \text { master rooms; } \\
8 \% \text { open plan } \\
\end{array}$ & $\begin{array}{l}\text { Moderate/Positive: } \\
\text { Some of the structures that are in place } \\
\text { for BSF didn't allow for changing the } \\
\text { way we work ...on some days, it felt like } \\
\text { we had no share of voice [Deputy Head] } \\
\text { The process, although we sometimes } \\
\text { might disagree, has been positive } \\
\text { [Head] }\end{array}$ & $\begin{array}{l}\text { Moderate: } \\
\text { We had to make the building smaller, } \\
\text { lost rooms, ended up with a joined } \\
\text { dining room-hall. But we're going to } \\
\text { have a wonderful school- it'll still give } \\
\text { us phenomenal opportunities [Deputy } \\
\text { Head] }\end{array}$ & $\begin{array}{l}\text { Underprivileged: } \\
\text { No additional funds } \\
\text { except for the } \\
\text { chapel (paid by } \\
\text { diocese) }\end{array}$ \\
\hline Paul & $\begin{array}{l}\text { Traditional: } \\
\text { Science area: only } \\
\text { traditional labs (7); } \\
\text { other faculty areas: } \\
100 \% \text { traditional }\end{array}$ & $\begin{array}{l}\text { Positive: } \\
\text { We were involved. There're always } \\
\text { constraints when you actually build-- } \\
\text { financial, building regulations, etc. You } \\
\text { cannot argue with these principles } \\
\text { [Head] }\end{array}$ & $\begin{array}{l}\text { Positive: } \\
\text { We ended up with a good design } \\
\text { [Head] } \\
\text { I actually think we probably got } 85 \% \\
\text { of our wish list. Didn't get a roof } \\
\text { garden, but can live with that [SEN } \\
\text { head] }\end{array}$ & $\begin{array}{l}\text { Somewhat } \\
\text { privileged: } \\
\text { Additional funds } \\
\text { from co-location } \\
\text { with SEN school }\end{array}$ \\
\hline David & $\begin{array}{l}\text { Traditional: } \\
\text { Science area: all } \\
\text { traditional labs }(8) \text {; } \\
\text { other faculty areas: } \\
100 \% \text { traditional }\end{array}$ & $\begin{array}{l}\text { Positive: } \\
\text { I think the process was successful. I } \\
\text { didn't find much tension working with } \\
\text { the Council ... as long as we were } \\
\text { careful in explaining what we wanted } \\
\text { [Deputy Head] }\end{array}$ & $\begin{array}{l}\text { Positive: } \\
\text { Our environment is very nice now. The } \\
\text { majority of the spaces are better than } \\
\text { the ones we had before, we rethought } \\
\text { adjacencies, and got nearly all of them } \\
\text { how we wanted [Deputy Head] }\end{array}$ & \begin{tabular}{|l|} 
Very privileged: \\
School raised $£ 2 \mathrm{~m}$ \\
in a fund drive to \\
refurbish old \\
facilities slated for \\
demolition
\end{tabular} \\
\hline
\end{tabular}


All in all, the design commons organization performed well in terms of satisfying the key interests of its participants, less well in terms of equitability, and poorly in terms of innovativeness. The satisfaction of the schools' leaders can be traced to their impact on the designs. One faculty head, for example, said:

[We were] given a blank canvas, it was, 'this is your space, how do you want it to work?' We were given a lot of freedom. ...I was able to say 'I need about 28 computers round the edge, a meeting area in the middle, a separate lecture area. ... If it doesn't work, it's my fault."

Although the design commons organization succeeded in producing designs that reasonably met the needs of teachers, a lack of equitability arose between schools with greater resources and those with more limited endowments. Gorton, for example, got a $£ 0.5 \mathrm{~m}$ loan from the Council to cover its courtyard and David launched a $£ 2 \mathrm{~m}$ fundraising campaign to cover the costs of extra work. In contrast schools like Matthews (which struggled to fund its chapel) believed they had compromised too much and felt less enthusiastic about the overall process. This suggests that while our observed commons recognized local variation and respected local rule-making (and rule-bending), it also replicated the distribution of wealth and resources across local districts.

In addition, despite the efforts of Council staff to push for open floor plans and other innovative measures, innovative designs did not prevail within the steering groups. One Council staff member said: “what we've got sadly ... is a number of 'new old schools'... [We] don't have a fully transformational school." In the final analysis, three schools opted for traditional designs and two for hybrid designs. Only Gorton wholeheartedly embraced the transformation agenda, and even there $52 \%$ of the non-science areas were laid out in a traditional manner. The locus of conservatism was in the schools' faculties, thus it seems likely that a centrally managed Council-driven design process, in which the schools did not have veto rights, would have resulted in more innovative building designs but less user satisfaction. In general, decentralized, incumbent-driven processes lead to compromise, hence higher levels of satisfaction among participants. However, such satisfaction may come at the expense of new ideas, which are inherently risky and may be threatening to incumbents (Tushman and Anderson, 1986). A commons organization is not the best way to solicit or obtain highly innovative designs. 
As it turns out, the Council's senior management and government watchdogs were happy to make this bargain. Like the schools' leaders, they too expressed satisfaction with the commons form of organizing. All projects in the first wave, with the exception of Abraham, got timely signoffs and were delivered within budget. Furthermore, no politically influential stakeholder derailed or overrode the process. The Council affirmed its satisfaction with the commons form of organizing when it chose to use the same approach in "wave 2" of the school-building program (which was equally successful).

The builders were content, too, because they appreciated working in an environment that did not lead to litigation. As one quipped, the margins were not high but neither were the risks. And for the architects, collaborations with schools like Gorton were very rewarding ("we're being exhorted to be transformational; the heads were great"), whereas others were less so ("if the school has its eyes closed, we'll deliver a more traditional design").

\section{BEYOND SIMPLE MIRRORING: WHEN AND WHY CREATE A DESIGN COMMONS ORGANIZATION?}

In this section, we return to the overarching question: when and why is a design commons an advantageous way to organize design work? It is important to note that Ostrom herself did not claim that one form of organization - even a commons - was optimal in all circumstances. A design commons organization is one of several ways to approach the design of a long-lasting, shared resource. Designers of design organizations might opt for one approach or another depending on their constraints and priorities. Our job here is to lay out the pre-conditions and tradeoffs leading to an informed choice.

A commons organization differs from government regulation in that it gives operational control of the resource to local agents and not to a top tier of bureaucrats. It differs from a private firm by providing for shared control, instead of control by a single owner. Local autonomy and shared control perforce give rise to many centers of legitimate decision-making, i.e., polycentricity. Thus, the defining properties of a design commons organization are: (1) polycentricity (many centers of power); (2) local autonomy; and (3) shared governance. 
As indicated, the existing theory of the relationship between design and organization structure is the "mirroring hypothesis." Mirroring implies that integral products should be designed by single authors or tight-knit teams within hierarchical organizations (bureaucracies or firms), whereas modular products can be designed by more loosely coupled organizations (Colfer and Baldwin, 2010). For projects with a high degree of design choice interdependency, a design commons organization violates strict mirroring in that it brings claimants who are not subject to hierarchical control into the design process, and gives them a substantive role and credible veto rights over the final outcome. For example, local users have direct, dayto-day knowledge of how an asset will be used, but they are not employees of a government agency or a private owner and thus are unlikely to have design rights ex officio. In a design commons organization, key user groups are not just consulted: they can propose and promote their own ideas and veto those of others. Thus, in a design commons (as in a natural-resource commons), key users and sometimes other claimants have credible stature, legitimacy, and direct influence, not because they control the purse strings or have property rights, but because they will be using the artifact or have other specific knowledge of its impacts.

Sharing decision rights among heterogeneous claimants to this extent has both costs and benefits. The most obvious cost is an increase in the risk of failure. If heterogeneous claimants insist on pursuing their own agendas at the expense of others', they may cause an already constrained, interdependent process to fail to arrive at a cost-effective design in a timely way. That said, in our setting, all designs except Abraham were delivered on time and within budget, and Abraham's design succeeded on the second round.

However, there was a more subtle cost in terms of the innovativeness of the final designs. Half the schools in our sample only paid lip service to the national agenda to create transformative buildings for learning. This finding coincides with other studies showing that incumbents rarely develop radical innovations (Morrison 1968, Tushman and Anderson 1986, Henderson and Clark 1990, Christensen 1997). To achieve a radical departure from the status quo, a different type of design organization, such as 
a skunk works or an entrepreneurial startup, is usually needed. Our observed commons organization also preserved the existing distribution of wealth and resources. Whether this outcome is a bona fide tendency of commons organizations or a consequence of the fragilities of the focal commons, e.g., insufficient accountability of monitors to all the participants, merits further research.

As its primary benefit, a commons organization creates an organization structure that induces a group of independent parties operating under a shared goal to invest time, effort, and knowledge in order to reconcile their differences. A robust commons organization recognizes, paraphrasing Ansari et al. (2013), that the claimants are part of the design problem and part of the solution. Our sample illustrates how, in the institutional context of a commons organization, all claimants were ready to cede a bit, working almost beyond the call of duty to succeed. Each school in our sample attested to spending 1,000 or more hours directly on design. The schools supplied time and knowledge freely and pursued the process to the end with great energy as did the Council staff and the contractors. Much of the teachers' knowledge was tacit, or "sticky" (von Hippel 1994) and could only be elicited and assimilated by the staff and contractors by having the teachers react to specific proposals and explain face-to-face why they wanted what they wanted. We conjecture that if the teachers had just been consulted and not given design rights, the final designs would have been poorer as a result.

A related benefit, documented in our research, was a high level of satisfaction among all the design participants and a concomitant perception of legitimacy for both the process and the outcomes. Importantly, the Council had great latitude in terms of how it enlisted different constituencies. The schools' faculties were the only user groups given design rights; other groups such as parents and community leaders were consulted but not given the power of veto. A robust design commons brings people who do not have ex officio design rights into the design organization, but it is still bounded and not open to every constituency. Low excludability is not the same as complete openness (Ostrom 1990).

In summary, the design commons form of organizing solves a problem of provision (of specific knowledge, effort, and time) at the cost of an increased risk of collective action problems leading to 
design failure. The solicitation and integration of knowledge and effort are fundamental problems that all organizations face (Lawrence and Lorsch, 1967; Puranam et al. 2011). On the one hand, a design commons organization increases the participants' incentives to contribute their knowledge and effort, but at the same time, it increases the difficulty and cost of integrating the various contributions. Indeed, our study suggests that, in a successful design commons organization, significant amounts of time must be spent in meetings to explain points of view, talk others into accepting ideas they were originally against, develop a shared language, and work out differences.

Ostrom argues that the risk of failure in a design commons organization can be mitigated by adhering to robust organizational principles. The Manchester design commons organization was not consciously designed using Ostrom's theory, but the commons literature shows that, using intuition and reasoning, people are capable of designing and adhering to effective rules. Relaxing or modifying the rules also turned out to be an important "adaptation mechanism” (O’Mahony and Bechky 2008) that acted as a safety valve. And importantly, in our sample, design flexibility was a crucial complement to governance. The architects' creativity in reconciling divergences allowed several steering groups to avoid impasse. Had flexibility not been used to attenuate subtractability, the commons organization might have collapsed.

\section{CONCLUSION}

In this paper we have argued that a design commons can be an advantageous form of organizing design work when two conditions are simultaneously present: 1) high "subtractability" of design choices because different claimants have conflicting beliefs or preferences with respect to an integral design form, and 2) low "excludability" because different claimants will share the designed artifact in use. These two conditions define a so-called common pool resource (Ostrom, 2006). They are also characteristic of many multi-party bargaining situations, including projects to develop long-lived assets such as hospitals, universities, factories, utility and transport networks, and other forms of physical infrastructure.

In the case of infrastructure assets, a key task for those with design rights by virtue of position is to 
set up the organization that will produce the actual design. Empirical accounts reveal again and again that those with design rights ex officio often opt not to share them with users and other potential claimants because they are well aware of the inherent collective action problems. Exclusion does not erase conflict, however. If the excluded parties are powerful and influential, they may try to sabotage the development process or lobby for changes that get increasingly costly and risky to implement as development unfolds (Morris 1987, Miller and Lessard 2001, Pitsis et al. 2003, Gil and Tether 2011). Hence an enduring goal in various literatures has been to search for organizational forms amenable to design change and concomitant trade-offs between flexibility and efficiency (cf. Pitsis et al. 2003).

Our main contribution to these literatures is to show that a robust commons organization is a viable alternative way to organize the production of designs for infrastructure assets that have a high degree of design-choice interdependency and also affect many heterogeneous groups. The commons form of organizing violates the precept of simple mirroring in that design rights for an integral structure are not contained within a centralized, hierarchical organization, but instead are distributed to parties that have conflicting beliefs and interests. Ex officio holders of design rights will share those rights selectively with knowledgeable parties, such as key user groups, in order to acquire valuable knowledge. The knowledge thus acquired serves to better align the final product with subsequent needs in use. Importantly, such knowledge is often tacit or "sticky", thus consultation, observation and statistical analysis will not suffice to overcome intrinsic barriers to communication. However, if a design commons organization is robust, its participants can, through rule-making and repeated interactions, integrate their knowledge, compromise on their interests, seek creative solutions, and in this fashion, reconcile their differences. Filtered through this process, the output of a successful design commons organization is a timely, makeable design for long-lived asset that many people can both share and afford.

Our second contribution is to extend commons theory to man-made artifacts, thereby enriching both commons theory and design theory. In the process, we have had to reconcile two disparate language systems. First, applying the terminology of commons theory, we showed that a design-in-process can be 
both subtractable and non-excludable, and thus qualify as a common pool resource subject to commons governance. Modular vs. integral design structure, budgets, and longevity determine subtractability. Nonexcludability is determined by ex officio design rights as well as shared use of the final constructed artifact. Specifically, when the final good must be shared by many people, detailed knowledge of use patterns and requirements is essential to enhance the design. However, such knowledge is often tacit or sticky, hence difficult to transfer. In such cases, it makes sense to relax de jure excludability by determining which individuals possess essential knowledge and then giving them effective decision rights in the design process.

In the process of applying commons theory to designs and design organizations, we also identified instances where commons theory is ambiguous in application. Most importantly, the principle of deference by outside authorities may pull in the opposite direction from access to low-cost conflictresolution mechanisms, especially when the authorities are claimants in their own right. We conjecture that, in some cases, it might be too easy - and not altogether advantageous - for commons participants to appeal to powerful outside referees. Working out conflicts at the operational level (e.g., within the steering groups) might be costly in terms of immediate time and energy, but it affirms the collective and polycentric nature of the organization and thus can contribute to its success.

Before concluding, we must emphasize that there are important limitations to the generalizability of this research. In the Manchester school design commons, the design requirements for each school were stable and each building was a separate site. Thus at the capital program level, the basic problem was large, but bounded and amenable to decomposition. The goal of the commons - to rebuild dilapidated schools - was also something all parties believed in, hence there was no conflict over purpose. The diversity in the backgrounds of the commons participants was limited: many had chosen careers of public service, and were residents or at least worked in the same city. Moreover, as a city, Manchester has a long history of civic pride, democratic socialism, and collective action. The schools' faculties were judged (by Ofsted) to be both competent and dedicated to their school's mission. Lastly, the tight rules for 
membership of the steering groups kept the "working commons" organizations relatively small. Through repeated private interactions, the individuals in the steering groups could develop trust and the norms of civility and reciprocity. It is not clear whether these pre-conditions were all necessary for the commons' success. Ostrom's own work suggests that incompetence and corruption, failures to develop norms of civility and joint problem-solving, and increases in inequality will undermine a commons organization. (But this is true of other organizational forms as well.)

In conclusion, our task in this paper has been to show that a design commons can be a useful way of organizing the design process for a long-lived non-modular asset that will be shared in use by many parties. Our research shows that this form of organizing, although it violates simple mirroring, does not inevitably lead to failure in spite of high interdependency among fundamental design choices. Furthermore, consistent with Ostrom's principles, sensible actions in terms of defining boundaries, making benefits proportionate to costs, and having authorities defer to local rule-making can increase the robustness of the commons organization and thus its chances of success. In sum, the design commons form of organizing recognizes that users (and others) are both a repository of valuable knowledge and a source of conflict. To get access to their knowledge, the designers of the design organization must accept the inevitability of conflict and put their faith in the good sense of human beings to resolve it.

\section{ACKNOWLEDGEMENTS}

We acknowledge the time and knowledge of all the Manchester Council staff, school teachers, and consultants who participated in this research. We give special thanks to Paul Maccabee-our first port of call for whenever we needed more data. We are also grateful for insightful discussions and comments by Marcela Miozzo, James Moore, Phanish Puranam, Christina Raasch, and participants in seminars at Stanford's Collaboratory for Research on Global Projects, DRUID, the University of Reading, Universita Luigi Bocconi and the University of Trento Summer School. Alden Hayashi provided valuable editorial advice. The authors are solely responsible for any errors, omissions, or inaccuracies. 


\section{REFERENCES}

Alston, L.J., Libecap, G.D., Schneider, R. (1985) Property Rights and the Preconditions for Markets: The Case of the Amazon Frontier. Journal of Institutional and Theoretical Economics, 151 (1) 89-107.

Ansari, S., Wijen, F., Gray, B. (2013) Constructing a Climate Change Logic: An Institutional Perspective on the "Tragedy of the Commons". Organization Science, 24 (4) 1014-1040.

Baker, G., Gibbons, R., Murphy, K.J. (2002) Relational Contracts and the Theory of the Firm. The Quarterly Journal of Economics 117/1 (February): 39-84.

Baldwin, C., Clark, K. (2000) Design Rules, Vol. 1, The Power of Modularity. Cambridge, MA, MIT Press.

Baldwin, C.Y., Clark, K.B. (2006) "The Architecture of Participation: Does Code Architecture Mitigate Free Riding in the Open Source Development Model?" Management Science 52(7):1116-1127.

Brooks, F.P. Jr. (1975) The Mythical Man-Month New York: Addison Wesley.

Building Bulletin 98 (2004) Briefing Framework for Secondary School Projects. Revision of BB82: Area Guidelines for Schools (Secondary section) Department for Education and Skills, UK.

CABE (2009) Designing Schools the Danish Way, 360², Issue 18 (Spring)

Christensen, C.M. (1997) The Innovator's Dilemma: When New Technologies Cause Great Firms to Fail Boston: Harvard Business School Press.

Colfer, L., Baldwin, C. (2010) The Mirroring Hypothesis: Theory, Evidence, and Exceptions. Working Paper 10-058, Harvard Business School.

Cornes, R., Sandler, T. (1986) The theory of externalities, public goods, and club goods. Cambridge University Press

Cox, M., Arnold, G., Tomás, S. V. (2010). A review of design principles for community-based natural resource management. Ecology and Society, 15(4), 38.

Dawson, B., Fixson, S.K., Whitney, D. (2012). Orchestrating Coordination: Reducing rework in complex product development. Technology, Operations, \& Information Management Working Papers. Paper 4. Babson College

DfES (2003) Classrooms of the Future. Innovative Designs for Schools, DfES, UK

Eisenhardt, K.M. (1989) Building Theories from Case Study Research. Academy of Management Review 14 (4) $532-550$.

Esty, B. C. (2004). Why study large projects? An introduction to research on project finance. European Financial Management, 10(2), 213-224.

Ethiraj, S. K., Levinthal, D. (2004a). Bounded rationality and the search for organizational architecture: An evolutionary perspective on the design of organizations and their evolvability. Administrative Science Quarterly, 49(3), 404-437.

Ethiraj, S. K., Levinthal, D. (2004b). Modularity and innovation in complex systems. Management Science, 50(2), 159-173.

Ferlie, E., F., L., Wood, M., Hawkins, C. (2005) The (Non) Spread of Innovations: The Mediating Role of Professionals. Academy of Management Journal 48(1) 117-134.

Fine, C. H. (1998) Clockspeed: Winning Industry Control in the Age of Temporary Advantage, Reading MA: Perseus Press. 
Frischmann, B. M. (2012). Infrastructure: The Social Value of Shared Resources. Oxford University Press.

Gardner, R., Ostrom, E., Walker, J. (1990) The Nature of Common-Pool Resource Problems. Rationality and Society 2: 335-58.

Gibbons, R. , Henderson, R. (2011) Relational Contracts and Organizational Capabilities. Organization Science 23: 1350-64.

Gil, N. (2009). Project Safeguards: Operationalizing Optionlike Strategic Thinking in Infrastructure Development. IEEE Transactions on Engineering Management, 56 (2) 257-270.

Gil, N., Tether, B. (2011) Project Risk Management and Design Flexibility: Analysing a Case and Conditions of Complementarity. Research Policy, 40, 415-428.

Gil, N., Miozzo, M., Massini, S. (2012) The Innovation Potential of New Infrastructure Development: An Empirical Study of Heathrow airport's T5 Project. Research Policy, 41 (2) 452-466.

Gordon, H.S. (1954) The economic theory of a common-property resource: The fishery. Journal of Political Economy, 62: 124-142.

Gray, B. (1989) Collaborating: Finding Common Ground for Multiparty Problems. San Francisco: Jossey-Bass.

Gulati, R., Puranam, P., Tushman, M. (2012) Meta-organization design: Rethinking design in interorganizational and community contexts. Strategic Management Journal 33(6) 571-586.

Hardin, G. (1968) The Tragedy of the Commons. Science 162: 1243-1248.

Henderson, R.M. , Clark, K.B. (1990) Generational Innovation: The Reconfiguration of Existing Systems and the Failure of Established Firms. Administrative Science Quarterly 35: 9-30.

Hess, C., Ostrom, E. (2007) Introduction: An overview of the knowledge commons in idem Understanding Knowledge as a Commons: From Theory to Practice, Cambridge, MA, MIT Press

Innes, J., Booher, D.E. (2010) Planning with Complexity: An Introduction to Collaborative Rationality for Public Policy. Oxford: Routledge/Taylor and Francis.

Jick, T. (1979) Mixing Qualitative and Quantitative Methods: Triangulation in Action Administrative Science Quarterly 24: 602-611.

Jacobs, E. 2013 Maestro of the Urban Skyline, Financial Times, 6/2/13.

Klein, P.G., Mahoney, J.T., McGahan, A.M., Pitelis, C.N. (2011) Institutional and Organizational Governance: Design Principles and Adaptation. University of Toronto working paper

Klein, P. G., Mahoney, J. T., McGahan, A. M., \& Pitelis, C. N. (2012). Who is in charge? A property rights perspective on stakeholder governance. Strategic Organization, 10(3), 304-315.

Langley, A. (1999) Strategies for Theorizing from Process Data Academy of Management Review 24: 691-710.

Langlois, R. N., Robertson, P.L. (1992). "Networks and Innovation in a Modular System: Lessons from the Microcomputer and Stereo Component Industries," Research Policy, 21(4): 297-313.

Lawrence, P. R., Lorsch, J. W. (1967) Differentiation and integration in complex organizations. Administrative Science Quarterly, 12 (1) 1-47.

Lessig, L. (2001) The Future of Ideas: The Fate of the Commons in a Connected World, Random House, New York, NY. 
Libecap, G.D. (1989) Contracting for Property Rights. Cambridge University Press, Cambridge, UK.

Lundrigan, C. and Gil, N. (2013). Megaprojects: A Hybrid Meta-organization. University of Manchester working paper. Available from http://ssrn.com/abstract=2324252

MacCormack, A., Baldwin, C.Y., Rusnak, J. (2012) Exploring the Duality Between Product and Organizational Architectures: A Test of the 'Mirroring' Hypothesis. Research Policy 41 (8) 13091324.

March, J., Simon, H. (1958) Organizations, New York, NY: Wiley.

Miles, M., Huberman, M. (1984) Qualitative Data Analysis: A Source Book for New Methods Beverly Hills, CA: Sage Publications.

Miller, C.C., Cardinal, L.B., Glick, W.B. (1997) Retrospective Reports in Organizational Research: A Reexamination of Recent Evidence. Academy of Management Journal 40: 189-204.

Miller, R. and Lessard, D. (2001) Strategic Management of Large Engineering Projects: Shaping Institutions, Risks, and Governance.MIT Press 2001.

Morris, P., Hough, G.H. (1987) The Anatomy of Major Projects: A Study of the Reality of Project Management. Wisley, Chichester.

Morrison, E. E. (1968) Men, Machines, and Modern Times. MIT Press.

Nickerson, J.A., Zenger, T.R. (2004) A Knowledge-based Theory of the Firm-The Problem-Solving Perspective, Organization Science, 15(6): 617-632

O'Mahony, S. (2003) "Guarding the Commons: How Community Managed Software Projects Protect Their Work," Research Policy 32(7):1179-1198.

O'Mahony, S. (2007). The governance of open source initiatives: what does it mean to be community managed?. Journal of Management \& Governance, 11(2), 139-150.

O’Mahony, S. , Bechky, B.A. (2008) Boundary Organizations: Enabling Collaboration Among Unexpected Allies. Administrative Science Quarterly 53: 422-459.

Olson, M. (1965) The Logic of Collective Action: Public Goods and the Theory of Groups. Cambridge, MA: Harvard University Press.

Orton, J. D., Weick, K. E. (1990). Loosely coupled systems: A reconceptualization. Academy of Management Review, 15(2), 203-223.

Ostrom, E. (1990). Governing the Commons: The Evolution of Institutions for Collective Actions Cambridge: Cambridge University Press.

Ostrom, E. (1998) A behavioral approach to the rational choice theory of collective action: Presidential address, American Political Science Association, 1997. American Political Science Review, 1-22.

Ostrom, E. (2005) Understanding Institutional Diversity Princeton NJ: Princeton University Press.

Ostrom, E. (2010) Beyond markets and states: polycentric governance of complex economic systems. The American economic review, 100(3) 641-672.

Ostrom, E., Gardner, R., Walker, J. (1994) Rules, games, and common-pool resources. University of Michigan Press.

Pitsis TS, Clegg SR, Marosszeky M, Rura-Polley T.(2003) Constructing the Olympic Dream: A Future Perfect Strategy of Project Management. Organization Science 14(5) 574-590.

Poppo, L. , T. Zenger, T. (2002) Do Formal Contracts and Relational Governance Function as Substitutes 
or Complements?" Strategic Management Journal 23/8 (August): 707-725.

Puranam, P., Alexy, O., Reitzig, M. (2011) What's 'New' About New Forms of Organizing?. Available at SSRN 1907542. Forthcoming in Academy of Management Review

Puranam, P., Goetting, M. (2011) Interdependence and Organization Design, manuscript, 20 June 2011.

Puranam, P., Raveendran, M., \& Knudsen, T. (2012). Organization design: The epistemic interdependence perspective. Academy of Management Review, 37(3), 419-440.

Raiffa, H. (1982) The Art and Science of Negotiations Cambridge, MA: Harvard University Press.

Romer, P.M. (1990) Endogenous Technological Change. Journal of Political Economy, 98(5) S71-S102

Sanchez, R. , Mahony, J.T. (1996) Modularity, Flexibility, and Knowledge Management in Product and Organization Design Strategic Management Journal 17: 63-76.

Schelling, T. C. (1960) The Strategy of Conflict Cambridge, MA: Harvard University Press.

Siggelkow, N. (2007) Persuasion with Case Studies Academy of Management Journal 50: 20-24.

Siggelkow, N., Levinthal, D. A. (2003). Temporarily divide to conquer: Centralized, decentralized, and reintegrated organizational approaches to exploration and adaptation. Organization Science, 14(6), 650-669.

Simon H.A. (1962) The Architecture of Complexity Proceedings of the American Philosophical Society 106: $467-482$.

Simon, H.A. (1981) The Sciences of the Artificial 2nd edition, Cambridge, MA: MIT Press.

Thompson, James D. (1967) Organizations in Action: Social Science Bases of Administrative Theory, New York, NY: McGraw-Hill.

Tushman, M. (1977) Special Boundary Roles in the Innovation Process Administrative Science Quarterly 22: 587-605.

Tushman, M.L., Anderson, P. (1986) Technological Discontinuities and Organizational Environments. Administrative Science Quarterly 31: 439-465.

von Hippel, E. (1994) Sticky Information and the Locus of Problem Solving: Implications for Innovation Management Science 40 (4) 429-439.

von Hippel, E., von Krogh, G. (2003) "Open Source Software and the 'Private Collective' Innovation Model: Issues for Organization Science," Organization Science, 14(2):209-223.

Wiggins, S.N., Libecap, G.D. (1985) Oil Field Unitization: Contractual Failure in the Presence of Imperfect Information. American Economic Review, 75: 376-385.

Williamson, O. E. (1991) "Comparative Economic Organization: The Analysis of Discrete Structural Alternatives," Administrative Science Quarterly, 36(2):269-296

Woolner, P., Hall, E., Higgins, S., McCaughey, C., Wall, K. (2007) A Sound Foundation? What We Know About the Impact of Environments on Learning and the Implications for Building Schools for the Future. Oxford Review of Education 33(1) 47-70.

Yin, R. (1984) Case Study Research: Design and Methods Los Angeles, CA: Sage Publishing.

Yoo, Y., Boland, R.J., Lyytinen, K. (2006) From Organization Design to Organization Designing. Organization Science 17(2): 215-229. 